
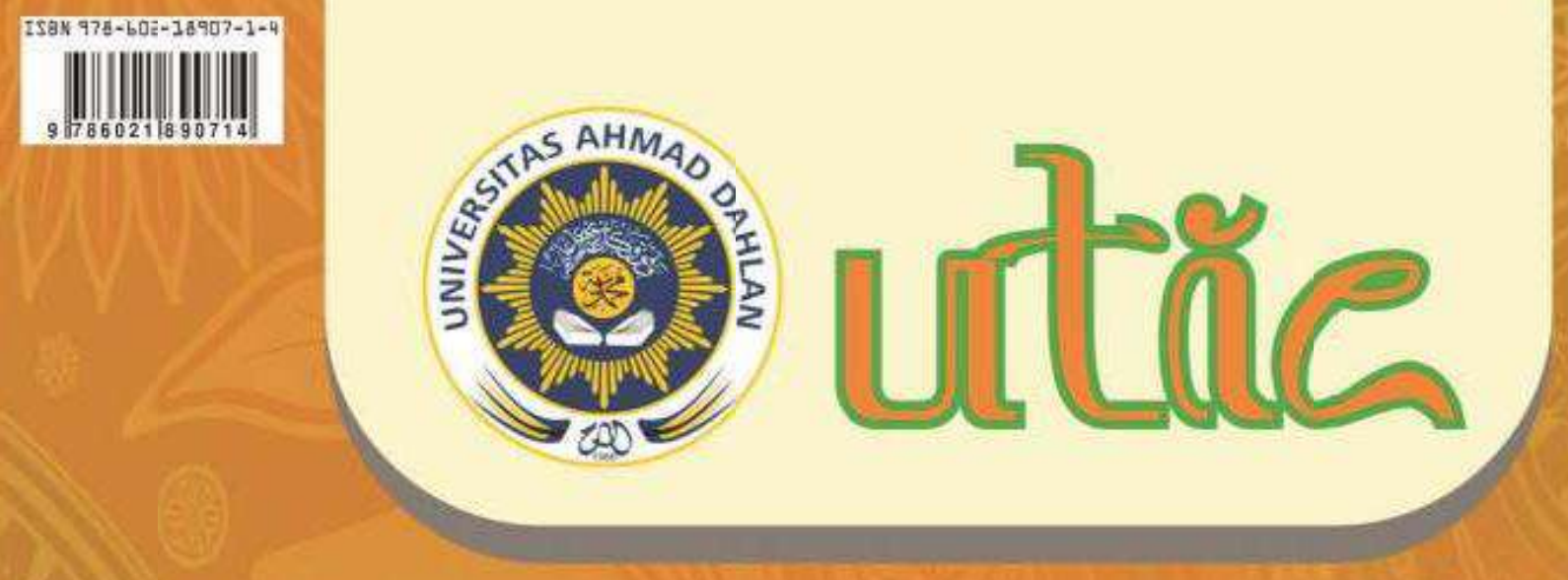

\title{
PROAM MDTES
}

\section{THE 3RD \\ UAD TEFL INTERNATIONAL CONFERENCE}

"ELT MATERIALS DEVELOPMENT IN ASIA AND BEYOND: DIRECTIONS, ISSUES, AND CHALLENGES"

ail

\section{E CAVINTON HOTEL YOGYAKARTA QU SEPTEMBER $17-18,2014$}

ENGLISH EDUCATION DEPARTMENT

FACULTY OF TEACHER TRAINING AND EDUCATION UNIVERSITAS AHMAD DAHLAN 


\section{THE THIRD UAD TEFL INTERNATIONAL CONFERENCE}

\section{PROCEEDINGS}

\section{"ELT Materials Development in Asia and Beyond: Directions, Issues, and Challenges"}

September $17-18,2014$

ISBN : 978-602-18907-1-4

(C) 2014. English Education Department of Universitas Ahmad Dahlan

This work is copyright. No part may be reproduced by any process without prior written permission from the organizing committee. Requests and inquiries concerning reproduction and rights should be addressed to Ani Susanti, M.Pd.BI at Universitas Ahmad Dahlan, Jalan Pramuka No 42 Yogyakarta Indonesia or email ani.susanti@pbi.uad.ac.id

The intellectual property of each paper included in these proceedings remains vested in the Authors as listed on the papers.

Published by :

English Education Department of Universitas Ahmad Dahlan

Jl. Pramuka No 42 Yogyakarta Indonesia

Telp : (+62274) 563515

Website: www.pbi.uad.ac.id 


\section{TABLE OF CONTENT}

COVER i

COPYRIGHT PAGE

PREFACE

iii

TABLE OF CONTENT.

Abdul Ngafif

The Use of ICT to Optimize Students' Testing Result

Agnesia Gita Flamboyan and Lies Amin Lestari

Developing English-Opoly Game as a Medium to Teach the 8th Graders Speaking

Recount Text

Ahmad Budairi

Digital literacy practices and L2 acquisition: Issues and challenges from Critical Pedagogy Perspectives

Aisyah

Note-Taking Pairs as a Technique in Enhancing Students' Reading Comprehension ....

Ali Mustofa

Literary Teaching and Its Constraints: Paradigms and Problems

Ana Maghfiroh

Enhancing Students' Communicative Competence through Daily Language

Activities

Ani Susanti

Crossword Puzzle in EFL Class: Nature and Strategies.

Annur Rofiq

Coping with the Need of Native Speakerism in Foreign Language Learning: Blending Strategy and Technology

Aryuliva Adnan

Listening Material Development: Problems and Challenges A Case Of 'PPG Sm-3t'

at Universitas Negeri Padang

Asep Nurjamin, Rajji K. Adiredja and Muhamad Taufik Hidaya Pre-Modified Text as Comprehensible Input in Reading Comprehension

Proceedings of The $3^{\text {rd }}$ UAD TEFL International Conference 2014 "Materials Development in Asia and Beyond: Directions, Issues, and Challenges" September 17-18, 2014, Yogyakarta, Indonesia Organized by English Education Department, Universitas Ahmad Dahlan 
Asih Santihastuti

Boosting Students' Motivation in Writing through a Meaningful and Fun Task:

A Descriptive Writing Bulletin.....

Astri Hapsari

Developing a Short Communicative Course in English: Materials Development for

Preparing Students to a Field Trip Abroad

Aulia Hanifah Qomar

Optimizing the Use of Internet Based Materials to Improve Students' Writing Skill in Developing Ideas

Aulia Nisa Khusnia

Fostering Teacher Strategies to Overcome Speaking Anxiety in EFL Classroom

Ayunita Leliana

Student-Centered Approach in Writing Class.

Badaruddin, Irvan Al Rajab, Syawal

Morphological Analysis strategy: A Strategy Used to Enhance the Student's

Vocabulary Acquisition and Reading Comprehension

Betty Sekarasih Hadi Yani

21st Century Learning Design Project Based Learning: School Campaign for Better

Future

Caecilia Tutyandari

Pre-Service Teachers' Self-Reflections in Micro Teaching Class.

Debora Tri Ragawanti

Utilizing Authentic Materials for Advancing Learners' Communicative Competence...

Dedi Turmudi

An Analysis on the Students' Trend in Writing Course.

Dedy Subandowo

Grammatical Function of Indonesian First Lady's Status of Photograph on Instagram with Focus on the Use of Subject.

Denok Lestari

Improving Communicative Competence through the Use of Language Functions in Role Playing.... 
Desak Putu Eka Pratiwi

The Meaning of Verbal and Non-Verbal Signs in the Advertisement of

Mineral Water "Ades".

Devi Pratiwy

Clipping in Malay Spoken Dialect

Devi Rachmasari

CIRC Method in Classroom Interaction to Enhance EFL Learners' Ability in Writing

Business Letters

Dewi Cahyaningrum

Process Approach to Using Questions in Listening to Activate Student's Listening

Strategies

Dewi Sartika and Rumiyati

Promoting Students' Speaking Skill by Using Pair Taping to the Eleventh Grade

Students of SMK PGRI Kayuagung....

Diah Hadijah dan Vidia L. Ayundhari

The Creativity Analysis through Creative Recount Text (Crt): A Suggested Writing

Material for EFL Learners

Didik Rinan Sumekto

Lecturers' and Students' Perception about Peer Assessment Practice: Benefits for

Collaborative Works

Dodi Siraj Muamar Zain

The Significances of Student Feedback in Improving the Quality of Language

Teaching

Dyah Kusumastuti

Recipes of Icebreaker in English Teaching Process

Ekaning Dewanti Laksmi

Developing Writing Instructional Materials to Accommodate 21st-Century Literacy

Skills: A R \& D Experience of an EFL Writing Teacher

Endang Setyaningsih

An Evaluation of the Use of Students Webquest Project in Reading Class

Endro Dwi Hatmanto

Pedagogy' Case Study at a Jesuit University in Yogyakarta 
Erwin Pohan

Character Building in Language Learning And Teaching

Etty M. Hoesein, Jeny Lekatompessy, Salmon Hukom, and Wa Ena

The Development of Local Context CALL Materials for EFL Instruction in Ambon....

Fardini Sabilah

Designing Intercultural Materials for EFL Teaching/Learning to Young Learners

Using Sociopragmatic Perspectives

Farnia Sari

Needs Analysis for English For Specific Purposes Course Development For Students of Economic Faculty, Tridinanti University....

Fauzul Aufa

RationaleTM: An Argument Mapping Software Tool to Promote Task-based

Argumentative Writing Instruction ...

Gita Mutiara Hati

Starting From Nothing: A Survival Guide For English Teachers of Young Language Learners

Gitit I.P. Wacana

Interpersonal Meaning in the Interaction between Teachers and Students: A Critical

Discourse Analysis

Gunadi H. Sulistyo, Sri Rachmajanti and Suharyadi

Developing Thematic Interactive Supplementary Reading Materials in a CD Form for Students of Elementary Schools with International Standards -Part II

Handan Girginer

Istanbul as an Authentic Material

Haryati Sulistyorini

Technology in Teaching Literature as the Effective Way in Film and Literary

Appreciation (Study of film Kung Fu Panda, Secret of The Furious Five)

Hayati Syafri

Build the Students' Character Energy through English Days Program (EDP) in STAIN

Bukittinggi

Hendriwanto

Developing the English Grammar Materials as a Source of the Students' Independent Learning 
Henny Herawati

Creative Writing in EFL Learning

Honest Ummi Kaltsum

Integrating Local Wisdom in the English for Young Learners

Ika Fitriani

In EFL Classroom: From Local to Global

Ima Widyastuti

A Processability Theory Study: Past -ed Acquisition in Indonesian Learners

Inggrit O. Tanasale

Third Place: Constructing Students' New Identities in Cross Cultural Understanding

Course

Intan Pradita

The Integration of Pragmatic Features to Stimulate Critical Thinking: A Material

Development for Argumentative Writing

Iskhak and Didih Faridah

Developing EFL Teacher Education Curriculum: A Needs Analysis-based Study at an Indonesian Private Teacher Training College.

Ista Maharsi

Students' Perception on Blended Learning: Opportunities and Challenges

Jamilah

Thematic-Integrated English Language Instruction for Music Education Department Students of Yogyakarta State University

Japen Sarage

Grammatical Conflicting Terms and Sentence Patterns in the Teaching of English.......

Jauhar Helmi

English Derivational Suffixes -y, -ity, and -ic in the Novel New Moon by Stephenie

Meyer and Its Translation

Jepri Ali Saiful

Eco-ELT Materials Development: The Proposed Idea towards Instilling the Concept of Loving the Environment and Upholding the Virtues of Local Wisdom to Young Learners 
Johanes Leonardi Taloko

The Teacher Talk Encountered in Intensive Course of the English Department of

Widya Mandala Catholic University Surabaya.

Juang Rudianto Putra, Tubagus Sumantri, and Sunsun Sunandar

Building EFL Students' Self-Confidence to Speak English

Junaedi Setiyono

Developing the Materials of Indonesian-English Translation by Applying Task-Based Language Teaching for English Department Students

Leni Irianti and Etika Rachmawati

Cognitive Strategies and Students' Learning Styles in Listening Comprehension

Leonora Saantje Tamaela

A Model of Pedagogic Songs for Teaching Language and Local Wisdom

Lia Novita

Teaching Translation of English Song Lyrics

Lusi Nurhayati

Promoting Higher Order Thinking Skills in Applied Linguistics Class

M. Mujtaba Mitra Z.

2013 Curriculum: Achieving Meaningful Communication through Involving Culture in Language Teaching and Learning

Manalullaili

Teaching Speaking for Slow Learners

Maria Johana Ari Widayanti

Motoric Developing Skills to Enhance Teaching English for Kindergarten Teachers ...

Maria Zakia Rahmawati

Creative Use of Haiku to Boost Students' Mastery of Vocabulary

Mariana Ulfah Hoesny

Project Based Learning in Writing Class

Marie Nica Ladesma-Enopia

From Reading Cognition to Practice: A Phenomenological Exploration toward a Model for College Reading Instruction 
Muhamad Ahsanu

Subconscious Learning of English via Chess Games: A Breaking Technique in SLA

(A Case Study)

Mukrim, Nurtria Rumbaen, Anita Thalib Mbau

The Students' Perceptions of Video-based Task in the English Speaking Classroom:

A Case Study at the Low English Proficiency of English Study Tertiary Students

Program

Ni Nyoman Padmadewi

Developing Media for Teaching English as a Foreign Language for a Special Needs

Student Included In A Regular Classroom at North Bali Bilingual School

Nia Rohayati

A Multi-Dimensional Approach to Developing and Using Authentic Reading

Materials

Nina Inayati

English Language Teachers' Attitude towards Social Media in Higher Education:

Indonesian Perspective

Nonny Basalama and Karmila Machmud

Exploring Teachers Understanding on the Issue of Plagiarism

Novianni Anggraini and Fithriyah Nurul Hidayah

A Study of Learning Style between Male and Female Students of IAIN Surakarta........

Novriani Rabeka Manafe

Investigating Learners' Perceptions on CLIL in Tertiary Context

Nuri Fainuddin

A Semiotic Analysis on Teaching English through Wayangs

Nurnaningsih

Improving the Students` Listening Skill by Using the Principles of Post method

Pedagogy for Twelfth Grade at SMA Negeri 5 Kota Bima

Paulus Widiatmoko

Developing Classroom Material to Encourage Integrated Skill Teaching

Puspa Dewi

Self-Editing Technique to Improve Students' Ability in Indonesian-English

Translation: An Experimental Research at English Department of Muhammadiyah

University of Purworejo 
R. Agus Budiharto

A Morphosyntactic Analysis on the University Students' Thesis Proposal in Madura...

866

Rajeevnath Ramnath

A Genre-Based Approach to Materials Writing

Ramdan Nugraha and Hermawan Susanto

Using Digitial Presentation in Teaching Speaking

Rasuna Talib

The Technique of Information Transfer for Teaching English In EFL Classroom

(Theoriesa and Practices)

Ratih Wahyu Korpriani

The Perception of Students' Reading-Aloud Strategies and Teachers' Reading-Aloud

Strategies in the EFL Teaching and Learning Process.

Renata C. G. Vigeleyn Nikijuluw

The Use of Four Corners Strategy to Improve Students' Reading and Speaking Skills at English Debating Club Pattimura University

Reni Herawati

Developing Teacher's Professionalism through Reflective Teaching

Ridha Mardiani

Student Perceptions Of Research in Developing Their Competence as English Teacher Candidates (A Case Study at the 2009 Batch Students).

Rina Agustina and Titi Wahyukti

Games for Teaching Writing Skills: A Suggested Technique for English Teachers.......

Rini Fatmawati

The Appropriateness of the Design of Structure Syllabus of the First Semester of

English Education of Muhammadiyah University of Surakarta

Rizki Farani

Effective Instructional Multimedia for English Learning

Rosina F.J. Lekawael and Hellien J. Loppies

Promoting Language Teachers Professionalism through GLPDN

(Global Literacy Professionalism Development Network) Project:

Why and How 
Sari Hidayati

The Use of Conversation Analysis Data as Authentic Input

Semi Sukarni

Applying CTL Model to Activate Students' Participation in Speaking Class at English Education Program

Sholihin

An Annotated Translation of "Techniques and Principles in Language Teaching"

(Teaching Techniques in English as A Second Language)

Siti Fatimah

Error Analysis in Listening Teaching Learning Process: a Case Study in English

Learning Process: a Case Study in English Department of

Muhammadiyah University of Surakarta

Siti Hajar, Khadijah Maming and Ika Yanti Ziska

The Implementation of Green Teaching as an Effort to Avoid the Global Warming

(A Great Expectation for Our Future)

Siti Mahripah

Exploring Factors Affecting EFL Learners' Speaking Performance: from Theories into Practices

Siti Nur Banin, Lies Amin Lestari

Developing a Prototype of Interactive Multimedia E-Book as a Medium

to Learn English

Sri Ninta Tarigan

The Application of Teacher Training Technique to Students of English Department Training and Education of Faculty University Of Prima Indonesia to Improve Learning Skill to Primary Students

Sri Sartini

Student's Use of Conversational Implicature in Academic Reading Class of Ahmad

Dahlan University Academic Year 2013/2014

Sri Subekti

Developing Task-Based Material for English Conversation (EC) Program at Grade

Eleven SMAN Plandaan Jombang

Susi Herti Afriani

Semantics Meaning Complexity in Combination of Predication (The Negated Antonyms) on English Paraphrase: Linguistics and Materials Developments 
Susiati

Parliamentary Debating Systems: a Debate Trend's Adoption to New English Speaking

Teaching Method in the 21st Century

Syahara Dina Amalia

Representations of National Character Building in Indonesian EFL Textbooks:

A Qualitative Study

Teguh Sarosa

Implementing Curriculum 2013 by Using Communicative Language Teaching

Theresia Widihartanti

The Efficacy of Using the Short Memory in Conducting English Proficiency Test

Thesa Izfadllillah

Character Building in Classroom Instruction: An Analysis on Lesson Plans

(A case study of English teachers at a K-13 piloting high schools in Sumedang)

Threesje. R. Souisa and Wenda M. Kakerissa

Improving Students' Reading Comprehension through the Application of the

Predict-O-Gram Strategy At X1 IPS Class of SMA Xaverıus Ambon

Tri Septiana Kurniati

The Importance of Lead-In Activity Method in Improving Motivation of English Speaking Ability among Non-English Department Students Applied in the Major of Graphics, Sculpture, and Painting, Fine Arts Department, Faculty of Art, Indonesian Art Institute of Yogyakarta, 2012-2013.

Veni Roza

The Power of Teacher Certification to the Teachers' Quality in English Learning Process at SMAN 1 Padang Panjang

Wuryani Hartanto

Students' Preferences of Functional-Communicative Based Materials in Their

Speaking Class

Wuwuh Andayani

Accessible Materials Used By the English Teacher and Students in Elementary Schools at the Ambal Sub District of Kebumen Regency 
Yenni Rozimela

Student Teachers' Conception of Materials Development: A Case at a Micro Teaching Class

Zaini Rohmad and Dewi Sri Wahyuni

Beyond Teacher Professional Program: English Writing Disabilities

Zusana E. Pudyastut, Jozua F. Palandi

A Correlation between Students' English Proficiency and Their Computer

Programming Mastery 


\title{
Lecturers' and Students' Perception about Peer Assessment Practice: Benefits for Collaborative Works
}

\author{
Didik Rinan Sumekto
}

\author{
Postgraduate Student of English Education \\ State University of Semarang, Indonesia; \\ Widya Dharma University, Klaten, Indonesia \\ didikrinan@unwidha.ac.id
}

\begin{abstract}
Recently classroom's peer assessment has strategic roles to be considered as an attempt in bridging students' collaboration works during writing course and recognizing their academic achievement while potentially conducting peer assessment practice. This study empirically records and investigates 5 writing lecturers' and 82 undergraduate students' perception about peer assessment practice as an alternative assessment from Tidar University of Magelang and Widya Dharma University, Klaten, Central Java. Research sampling applied the simple random sampling technique. Data analysis are carried out by SPSS program and examined quantitatively by applying descriptive statistics based on the questionnaire data. The findings indicate that there are nine indicators ranking on the significant level and the most significant indicator relates to students' competence matter above the delivered learning themes, where mean $(M)$ is 3.80 and standard deviation $(S D)$ value is .447 based on the writing lecturers' perception. Meanwhile, there are $75.6 \%$ or 62 of English education undergraduate students perceive that peer assessment has granted their writing contribution through the collaboration works, in which there are twelve supporting indicators available to strengthen the participants during their writing collaboration works. Overall, students' perception about peer assessment practice contributes participation during its implementation, where mean $(M)$ is 3.51 and standard deviation $(S D)$ is .599 .
\end{abstract}

Keywords: Collaboration, peer assessment, perception

\section{Introduction}

The assessment term is recently determined as one of the most emotive words in higher education lexicon among stakeholders (e.g. anxiety, pressure, competition, success, failure, feedback, fairness, standards, and accountability) depending on the nature of participation in the formative and summative assessment process carried out by experts, peers and oneself (Berry and Adamson, 2011). Formative

\section{0}

Proceedings of The $3^{\text {rd }}$ UAD TEFL International Conference 2014 "Materials Development in Asia and Beyond: Directions, Issues, and Challenges" September 17-18, 2014, Yogyakarta, Indonesia Organized by English Education Department, Universitas Ahmad Dahlan 
assessment evaluates students in the process of forming their competencies and skills with the goal of assisting them to continue the growth process of appropriate feedback on instruction performance, with the progressive sustainability of learning. Meanwhile, summative assessment aims to measure and summarize what students have grasped and typically lead at the end of a course or instruction unit in the classes (Brown, 2004). Further, this assessment mechanism is to make judgments of the individual performance or the system effectiveness, and to improve learning. It is usually carried out in order to evaluate academic achievement suitability to perform other relevant particular tasks in education level (Berry and Adamson, 2011).

In the educational setting, the assessment aspects seek answers to one or more of the following connected questions, namely: (1) how well are students' learning in English education system; (2) does learning evidence indicate particular strengths and weaknesses in the students' knowledge and skills; and (3) what factors are associated with the students achievement (Greaney and Kellaghan, 2008). However, as the alternative mechanism, peer assessment model provides the students with opportunities to be involved in the process of assessment and to engage in questioning, marking and feedback and be a more active participant within their own learning environment (Philpott, 2009). A well-organized peer assessment might not only focus on peer understanding of instructional theory and practice but also enhance the development of a repertoire of professional skills through explanations, justifications of claims, and communication with peers during post-lesson reflective dialogues (Nyaumwe and Mtetwa, 2006).

In practice, peer assessment is uniquely valuable since the interchange is in language that the students will naturally use, by taking the roles of lecturer(s) and other examiners, and they appear to find it easier to make sense of criteria for their work if participants examine other participants' work alongside their own (Gardner, 2006). Peer assessment involves participants and other participants to a greater sense of accountability, motivation and responsibility, and an increase in the speed of feedback (Black et al, 2003; Bloxham and Boyd, 2007) as well as increases understanding of the subject matter, standards required, learners' own achievement, disciplinary knowledge and skills in order to make judgments (Bloxham and Boyd, 2007), develop important skill for lifelong learning, such as such as self-evaluation, giving feedback, justifying a point of view and negotiation skills (Boud, 2000; Bloxham and Boyd, 2007).

\section{Literature Review}

\subsection{Previous study}

The empirical findings on peer assessment implementation have been revealed that pre-service teachers' confidence in using the method more likely to increase if the method is introduced at an early stage in the program and in a consistent manner. Pre-service teachers who are better prepared to use peer assessment are

\section{1}

Proceedings of The $3^{\text {rd }}$ UAD TEFL International Conference 2014 "Materials Development in Asia and Beyond: Directions, Issues, and Challenges" September 17-18, 2014, Yogyakarta, Indonesia Organized by English Education Department, Universitas Ahmad Dahlan 
more inclined to accept the method than are their predecessors who have been given less preparation. It will be beneficial to discuss issues related to fairness and bias in the assessment process as well as the implications of misusing or abusing the assessment. There is confidentiality during their preparation for the use of peer assessment (Sivan, 2000).

Then, the involvement of peers in assessment, according to Nyaumwe and Mtetwa (2006) has motivational and cognitive merits. From a motivational perspective, peer collaborative assessments contribute to feelings of control regarding how the pre-service teachers learn, gain confidence, and understand how to implement constructivist instructional strategies in their instruction. In the post-lesson reflective dialogue, a peer and a lecturer identify an episode from the assessed lesson and use personalized understanding of constructivist tenets to interpret it. A pedagogical discourse provides opportunities for peers and lecturer to reflect, exchange alternative perceptions, and negotiate a consensus that can be generalized to instructional practices of other concepts. This finding has shown that the lecturer-peer assessments are effective for both formative and summative evaluation purposes.

Furthermore, Matsuno (2009) points out that peer assessment can possibly supplement lecturers' assessment and compensate for shortcomings in lecturer's assessment. The peer-assessors are internally consistent, their rating patterns are not dependent on their own writing performance, and fewer biases were produced by peer-raters than self- and lecturer-raters. These findings underlines that peerraters have the potential to make important contributions to the overall assessment process.

\subsection{Bridging peer assessment: An alternative assessment}

Either assessment or instruction are critical for higher education students (Schulz, 2009) and nowadays, the increase in the use of teaching and learning strategies in which pre-service teachers learn with and from each other may result in an increase in the peer assessment use. Peer assessment may be used to determine the allocation of a group's marks to individual learners (Ammons and Brooks, 2011). When students conduct peer assessments in collaborative learning environments, they have an opportunity to discuss and analyze each other's performance. Peer assessment is able to provide a means by which group marks are allocated among the members of a group based on their relative contributions (Ghorpade and Lackritz, 2001; Falchikov and Magin, 1997; Ammons and Brooks, 2011). Peer assessments affect a significant proportion of the total marks for a course exists in EFL students' peer assessments (Falchikov and Magin, 1997; Ammons and Brooks, 2011) and provides them with opportunities to be involved in the process

\section{2}

Proceedings of The $3^{\text {rd }}$ UAD TEFL International Conference 2014 "Materials Development in Asia and Beyond: Directions, Issues, and Challenges" September 17-18, 2014, Yogyakarta, Indonesia Organized by English Education Department, Universitas Ahmad Dahlan 
of assessment and to engage in questioning, marking and feedback and be a more active participant within their own learning environment (Philpott, 2009).

Peer assessment involves participants in giving feedback to peers. In peer assessment, marks can be awarded by participants or negotiated with lecturer. Marks may or may not be used for formal grading purposes and a key aim of peer assessment is to enhance learning. It more closely resembles lecturer assessments when students are required to make global judgments based on clear and explicit criteria, and when they are familiar with, and have some degree of ownership of, the criteria, rather than when grading involves assessing several individual dimensions (Falchikov, 2001). Peer assessment may initiate scrutiny and clarification of the objectives and purposes, criteria and marking scales of assessment, and indeed the objectives of the course itself. It may also have an impact on affect, increasing motivation through an enhanced sense of ownership and personal responsibility, greater variety and interest, activity and inter-activity, and also improving self-confidence, identification and bonding, and empathy with others for either assessors or assesses. It has also been proposed that peer assessment might increase a range of social and communication skills, including negotiation skills and diplomacy, verbal communication skills, giving and accepting criticism, justifying one's position and assessing suggestions objectively (Topping et al, 2000) and students' involvement in peer assessment are engaging with criteria and standards, and applying them to make judgments (Falchikov and Goldfinch, 2000) on the language performance (Brown, 1998). Referring to its implementation, peer assessment can be classified into inter- and intra-group as shown in figure 1. For intra-group assessment, each participant assesses the contribution of that group's other members to the written and/or presentation works, whereas inter-group assessment assesses the other groups' works (Sivan, 2000).

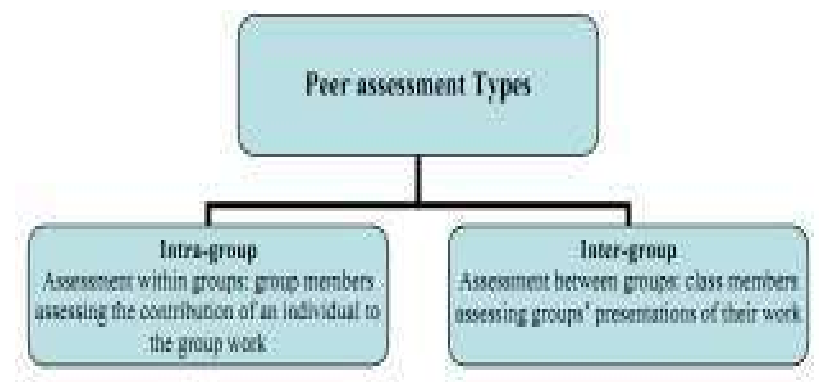

Figure 1. Peer Assessment Types

Peer assessment usually takes place during the meetings time, or partially out of classroom (Topping, 1998). In giving guidance on peer assessment

\section{3}

Proceedings of The $3^{\text {rd }}$ UAD TEFL International Conference 2014 "Materials Development in Asia and Beyond: Directions, Issues, and Challenges" September 17-18, 2014, Yogyakarta, Indonesia Organized by English Education Department, Universitas Ahmad Dahlan 
implementation, hence, Falchikov and Goldfinch (2000) provide six recommendations, namely: (1) avoid using very large numbers of peers per assessment group; (2) conduct peer assessment studies in traditional academic settings and involve students in peer assessment of academic products and processes; (3) do not expect student assessors to rate many individual dimensions. It is better to use an overall global mark with well understood criteria; (4) involve students in discussions about criteria; (5) pay great attention to the design, implementation and reporting of your study; and (6) avoid the use of proportions of agreement between peers and lecturers as a measure of validity. It is generally acknowledged that in order to assess learners' learning, proficiency, and knowledge, herewith peer assessment can be defined as an arrangement for peers to consider the level, value, worth, quality or successfulness of the products or outcomes of learning of others of similar status (Topping et al, 2000; Matsuno, 2009). In the field of first language pedagogy, peer-assessment has also been considered as an effective tool in both group and individual projects. Peer assessment has been found to assess each student's efforts in group projects and to help them learn more and work collaboratively in a group. In individual tasks, participants will be more involved in assessment and instruction, which leads to greater satisfaction within the meetings (Sluijsmans, Brand-Gruwel, and Marriënboer, 2002; Matsuno, 2009).

By giving an understanding on peer assessment, Topping (1998) claimed that peer assessment might cognitively create effects by increasing a number of variables for either assessors or assesses. These variables could include levels of time on task, engagement, and practice, coupled with a greater sense of accountability and responsibility. Peer assessment analyzes earlier errors and misconception identification analysis. This will lead to the identification of knowledge gaps and to the engineering of their closure through explaining, simplifying, clarifying, summarizing, reorganizing, and cognitive restructuring. However, Bamberger et al (2005) emphasize that the assessment of a peer is a behavior just like the behavior being assessed, and therefore peer assessor evaluative decisions will be guided by strategic considerations. Peer assessment principle (Falchikov, 2001) in this regard is to encourage both the increase in learners quantity entering into higher education level and a growing belief that students need to practice the skills in order to equip them for work, leisure and lifelong learning since group working brings with it many benefits as well. For the real construct, sometimes learners find themselves working in the absence of a lecturer, thus, this assessment scheme moves from the product of learning objectivity to its processes orientation. 


\subsection{Research questions}

The following research questions are investigated in this study:

2.3.1 Is there a significant difference between lecturer's and undergraduate students' perception about peer assessment practice during the collaborative writing works?

2.3.2 How beneficial is the peer assessment in assessing undergraduate students writing instruction?

\subsection{Research objectives}

Relating to lecturers' and students' perception about peer assessment practice engaged in collaborative writing works, thus this study (1) examines both what drives lecturers' and undergraduate students' perception about peer assessment practice and (2) how the benefits impact lecturers' and undergraduate students' collaborative writing works in order to attain better design and implementation of peer assessment practice.

\section{Methods}

\subsection{Participants}

During the first semester in the academic year 2012/2013, this study carried out of eighty two $(n=82)$ students and five $(n=5)$ writing lecturers participating in a peer assessment practice to reveal the benefits for collaborative writing works. The undergraduate students were randomly chosen as participants. The determination was 42 participants from Tidar University of Magelang and 40 participants from Widya Dharma University of Klaten, Indonesia majoring in English education. Meanwhile, 5 lecturers ( $\mathrm{n}=2$ from Tidar University; $\mathrm{n}=3$ from Widya Dharma University) who taught the writing course were definitely selected for this study purposes. According to McMillan and Schumacher (2001), the sample size determination should give impacts to the research design, benefits, focusedvariables, data collection technique, and empirical findings.

\subsection{Procedure and Data analysis}

Responses in peer assessment practice questionnaire data were processed to calculate the average score (mean and standard deviation) across the whole respondents. Data was collected from the returned quantitative surveys. Respondents were required to cross one of the indicators that corresponded to the notion of frequency (Dunn et al, 2004). Firstly, there had been nine statements of peer assessment importance and secondly, twelve statements of peer assessment practice for collaborative writing work benefits were included. All data was quantitatively examined by statistical descriptive testing through the SPSS program. The average score (mean) was considered as an indication of how important the collaborative writing works amongst the respondents' point of view. Responses were expressed in a Likert scale, starting from 1 to 5 (5 meaning "very important", 4 meaning "important", 3 meaning "moderate", 2 meaning "less

\section{5}

Proceedings of The $3^{\text {rd }}$ UAD TEFL International Conference 2014 "Materials Development in Asia and Beyond: Directions, Issues, and Challenges"

September 17-18, 2014, Yogyakarta, Indonesia

Organized by English Education Department, Universitas Ahmad Dahlan

ISBN: 978-602-18907-1-4 
important", and 1 meaning "not important"). The only exceptions were two items attached in table 1, where the respondents only provided their response by answering "Yes" or "No" for peer assessment implementation.

\section{Finding and Discussion}

This data analysis began with the descriptive analysis on lecturers' perception about peer assessment practice. Table 1 indicated a survey finding which supported twelve indicators about writing instruction taught within collaborative works method amongst the undergraduate English education students. Out of twelve indicators revealed, overall mean $(M)$ score ranged in between 3.20 to 3.80 had contributed significant results. However, in accordance with the descriptive result presented, there was notably found that the materials delivered to students' competence contributed the highest score (mean=3.80) and writing indicators related to students' competence contributed the lowest score (mean=3.20).

\begin{tabular}{|c|c|c|c|c|c|c|}
\hline \multirow[t]{2}{*}{ Indicators } & \multicolumn{6}{|c|}{ Writing Leaturers - Tidar S. WSdya Dharma Lniversity } \\
\hline & $\mathrm{Mn}$. & Mor. & Mesn & Medien & SD & N \\
\hline Materials relate with student's competence & 3.00 & $4: 00$ & 390 & 4.00 & 447 & 5 \\
\hline Writing zuidance is clesr enough & 260 & 4,20 & 3.52 & 3.60 & 593 & 5 \\
\hline Writing steps is in chronological arder & 300 & 3.80 & 3.48 & 3.60 & 303 & 5 \\
\hline Wrating ind cators ralate with students' compatence & 233 & 3.67 & 320 & 3.66 & 649 & 5 \\
\hline instructional matecial has been appropriate & 2.60 & 3,80 & 3.40 & 3.60 & 469 & 5 \\
\hline $\begin{array}{l}\text { Solected themes have been appropriate with the genre-baced } \\
\text { meetings }\end{array}$ & 300 & 4.DD & 3.70 & 4.00 & 447 & 5 \\
\hline Providirs relevent sssigrments to stuidents & 250 & 4.00 & 3.40 & 3.50 & 651 & 5 \\
\hline $\begin{array}{l}\text { Foodback procass toward students' motivation is approprate } \\
\text { eneugh }\end{array}$ & 3.00 & 4:Do & 3.53 & 3.66 & 330 & 5 \\
\hline Assignment instruments based on the probiem-based learnurs & 3.17 & 3.83 & 3.46 & 3.50 & 298 & 5 \\
\hline Learning terminology is applicable for lesson plan & 3,00 & 4.00 & 3.60 & 3.50 & 418 & 5 \\
\hline $\begin{array}{l}\text { Accoedingty easy to resume some spectic terminolagies on your } \\
\text { lesson plas? }\end{array}$ & 2.50 & 4.00 & 330 & 3.50 & 570 & 5 \\
\hline $\begin{array}{l}\text { Evaluation is sppropriately done in wrating meetings (refering } \\
\text { to lessan gian) }\end{array}$ & 2.50 & $3.7 \mathrm{~B}$ & 3.49 & 3.54 & 347 & 5 \\
\hline
\end{tabular}

Another finding was shown in table 2 relating to some peer assessment practice indicators gained by students during their writing collaborative experience. There was empirically described that $12 \%$ or 24 participants perceived on peer assessment implementation was fair enough to support their writing collaborative works; $19.3 \%$ or 38 participants conveyed that peer assessment activities enabled to criticize the students' works and corrected their mistakes, this indicator ranked on the highest position; $11.1 \%$ or 22 participants revealed their perception on peer

\section{6}

Proceedings of The $3^{\text {rd }}$ UAD TEFL International Conference 2014 "Materials Development in Asia and Beyond: Directions, Issues, and Challenges" September 17-18, 2014, Yogyakarta, Indonesia Organized by English Education Department, Universitas Ahmad Dahlan 
assessment which enabled to motivate and create esprit de corps in writing collaborative works; $14 \%$ or 28 participants put their perception on peer assessment that enabled to reduce the lecturers' roles and subjectivity; $17.1 \%$ or 34 participants determined their peer assessment experience which supported to joyfulness and flexibility implementation; and $9 \%$ or 18 participants stated that peer assessment activities were more democratic than lecturers' assessment, this indicator ranked on the lowest level of assessment practice during the collaborative writing works.

Overall, peer assessment practice reflected students' involvement in which they were engaging with criteria and standards, and applying them to make judgments (Falchikov and Goldfinch, 2000) on the collaboration. Table 3 strengthened the descriptive analysis as well how undergraduate students of English education from Tidar University of Magelang and Widya Dharma University of Klaten had been in collaboration to support the benefits for their writing works. The significant output proved the mean $(M)$ was 3.51 and standard deviation $(S D)$ was .599 .

Table 2. Peer Assessment Practice Indicator Gained by Students

\begin{tabular}{lc}
\hline $\begin{array}{l}\text { Peer assessment is fair enough as each } \\
\text { student to evaluate others }\end{array}$ & $24(12.0 \%)$ \\
\hline $\begin{array}{l}\text { Peer assessment activities are able to criticize } \\
\text { the students' works and correct mistakes }\end{array}$ & $38(19.3 \%)$ \\
$\begin{array}{l}\text { Peer assessment activities enable to motivate } \\
\text { and create esprit de corps in writing } \\
\text { collaborative works }\end{array}$ & $22(11.1 \%)$ \\
$\begin{array}{l}\text { Peer assessment enables to reduce the } \\
\text { lecturers' roles and subjectivity }\end{array}$ & $28(14.0 \%)$ \\
$\begin{array}{l}\text { Peer assessment involves joyfulness and } \\
\text { flexibility during its implementation }\end{array}$ & $34(17.1 \%)$ \\
$\begin{array}{l}\text { Peer assessment activities are more } \\
\text { democratic than lecturers' assessment }\end{array}$ & $18(9.0 \%)$ \\
\hline
\end{tabular}

Proceedings of The $3^{\text {rd }}$ UAD TEFL International Conference 2014 "Materials Development in Asia and Beyond: Directions, Issues, and Challenges" September 17-18, 2014, Yogyakarta, Indonesia Organized by English Education Department, Universitas Ahmad Dahlan ISBN: 978-602-18907-1-4 


\section{The $3^{\text {rd }}$ UAD TEFL International Conference 2014}

\begin{tabular}{|c|c|c|}
\hline Participant & & $\begin{array}{r}\text { Students' involvement } \\
\text { in Peer Assessment }\end{array}$ \\
\hline \multirow{7}{*}{ Tidar Univ. of Magelang } & Min & 2.60 \\
\hline & Max & 4.60 \\
\hline & Mean & 3.64 \\
\hline & Median & 3.70 \\
\hline & SD & .522 \\
\hline & $\mathbf{N}$ & 40 \\
\hline & Min & 2.33 \\
\hline \multirow{10}{*}{$\begin{array}{l}\text { Widya Dharma Univ. of } \\
\text { Klaten }\end{array}$} & Max & 5.00 \\
\hline & Mean & 3.37 \\
\hline & Median & 3.20 \\
\hline & SD & .649 \\
\hline & $\mathbf{N}$ & 42 \\
\hline & Min & 2.33 \\
\hline & Max & 5.00 \\
\hline & Mean & 3.51 \\
\hline & Median & 3.60 \\
\hline & SD & .599 \\
\hline Total & $\mathbf{N}$ & 82 \\
\hline
\end{tabular}

Moreover, as summarized in table 4 there would be described through the peer assessment contribution that both participants from Tidar University and Widya Dharma University $(\mathrm{n}=82)$ were required to answer 'yes' or 'no' whether peer assessment really contributed to their writing collaborative works during the classroom course. Definitely they presented that there were $75.6 \%$ or 62 participants responding to 'yes' which meant more than half participants agreed if peer assessment contribution supported to their writing collaborative works. Nevertheless, there were $14.6 \%$ or 12 participants who did not agree by responding 'no' that peer assessment contribution might not support to their writing collaborative works and there were still $9.8 \%$ or 8 participants who were 'not responding' towards this assessment benefit. 
The $3^{\text {rd }}$ UAD TEFL International Conference 2014

Table 4. Peer Assessment Contribution in Writing Collaborative Works

\begin{tabular}{llll}
\hline \hline \multirow{2}{*}{ Category } & \multicolumn{2}{c}{ Participants } & Total \\
\cline { 2 - 3 } & $\begin{array}{l}\text { Tidar University of } \\
\text { Magelang }\end{array}$ & $\begin{array}{l}\text { Widya Dharma } \\
\text { University of Klaten }\end{array}$ & \\
\hline No & $30(71.4 \%)$ & $32(80.0 \%)$ & $62(75.6 \%)$ \\
Not responding & $6(14.3 \%)$ & $6(15.0 \%)$ & $12(14.6 \%)$ \\
& $6(14.3 \%)$ & $2(5.0 \%)$ & $8(9.8 \%)$ \\
$\quad$ Total & $42(100.0 \%)$ & $40(100.0 \%)$ & $82(100 \%)$ \\
\hline \hline
\end{tabular}

\section{Conclusion}

Reviewing critically to a peer assessment of collaborative writing works in the academic perspective at higher education level will certainly invite and initiate both students and lecturer participations during the process. Both parties are engaged fairly and equally inside the process due to its role's responsibility. In this regard, lecturer takes a position accordingly as a facilitator merely in the class and gives more opportunity to students to demonstrate their roles and capability of assessing peers' works in progress. Summarizing from the research questions, hence, peer assessment practice can be drawn into the following: (1) direct involvement amongst the participants (e.g. lecturers and students) creates their own autonomy encouragement, and increased a collaboration between lecturers and students, gave a trust from lecturers perspective, and improved motivation; (2) a positive effect leads an emergence as a consequence of the enhanced degree of monitoring inherent during the process and continuity; (3) and the beneficial effect of peer assessment with respect to the level of individual initiative and collaborative works including behavior, for instance peer mentoring, teamwork, and motivation to assist in the achievement of group objectives will be accommodative. This criteria relates to some supporting indicators in peer assessment practice, such as peer assessment is fair enough to evaluate other participants; peer assessment enables to criticize the students' works and correct mistakes; peer assessment enables to motivate and create esprit de corps in writing collaborative works; peer assessment is able to reduce the lecturers' roles and subjectivity which also involve joyfulness and flexibility during its implementation; and peer assessment activities are more democratic than lecturers' assessment in accordance with each . It indicates that 62 or $75.6 \%$

\section{9}

Proceedings of The $3^{\text {rd }}$ UAD TEFL International Conference 2014 "Materials Development in Asia and Beyond: Directions, Issues, and Challenges" September 17-18, 2014, Yogyakarta, Indonesia Organized by English Education Department, Universitas Ahmad Dahlan 


\section{The $3^{\text {rd }}$ UAD TEFL International Conference 2014}

participants agree about peer assessment contribution supports the collaborative works on writing course.

\section{References}

Ammons, J. L., \& Brooks, C, M. 2011. An empirical study of gender issues in assessments using peer and self evaluations. Academy of Educational Leadership Journal, 15, 49-62.

Bamberger, P. A., Erev, I., Kimmel, M., \& Oref-Chen, T. 2005. Peer assessment, individual performance, and contribution to group processes: The impact of rater anonymity. Group \& Organization Management, 30(4), 344-377.

Berry, R., \& Adamson, B. 2011. Assessment reform in education: Policy and practice. In Berry, R., \& Adamson, B, Reform Past, Present and Future (Pp. 3-14). London: Springer Science Business Media B.V.

Black, P., Harrison, C., Lee, C., Marshall, B., \& William, D. 2003. Assessment for learning: Putting it into practice. Maidenhead: Open University Press.

Bloxham, S., \& Boyd, P. 2007. Developing effective assessment in higher education: A practical guide. Berkshire: Open University Press.

Boud, D. 2000. Sustainable assessment: Rethinking assessment for the learning society. Studies in Continuing Education, 22(2), 151-167.

Brown, H. D. 2004. Language assessment: Principles and classroom practices. New York: Pearson Education, Inc.

Brown, J. D. 1998. New ways of classroom assessment. Virginia: Teachers of English to Speakers of Other Languages, Inc.

Dunn, L., Morgan, C., O’Reilly., \& Parry, S. 2004. The student assessment handbook. London: RoutledgeFalmer-Taylor \& Francis Group.

Falchikov, N. 2001. Learning together: Peer tutoring in higher education. London: RoutledgeFalmer.

Falchikov, N., \& Magin, D. 1997. Detecting gender bias in peer marking of students' group process work. Assessment and Evaluation in Higher Education, 22(4), 385-397.

Falchikov, N., \& Goldfinch, J. 2000. Student peer assessment in higher education: A meta-analysis comparing peer and teacher marks. Review of Educational Research, 70(3), 287-322.

Gardner, J. 2006. Assessment and learning. In Gardner, J, Assessment and learning: An introduction (Pp. 1-25). London: SAGE Publications Ltd.

Ghorpade, J., \& Lackritz, J. R. 2001. Peer evaluation in the classroom: A check for sex and race/ethnicity effects. Journal of Education for Business, 76(5), 274-382.

Greaney, V., \& Kellaghan, T. 2008. Assessing national achievement levels in education. Washington: The International Bank for Reconstruction and Development/ The World Bank.

Matsuno, S. 2009. Self-, peer-, and teacher-assessments in Japanese university EFL writing classrooms. Language Testing, 26(1), 75-100.

McMillan, H. J., \& Schumacher, S. 2001. Research in education: A conceptual introduction $\left(5^{\text {th }} e d\right.$.). New York: Addison Wesley Longman, Inc.

\section{0}

Proceedings of The $3^{\text {rd }}$ UAD TEFL International Conference 2014

"Materials Development in Asia and Beyond: Directions, Issues, and Challenges"

September 17-18, 2014, Yogyakarta, Indonesia

Organized by English Education Department, Universitas Ahmad Dahlan

ISBN: 978-602-18907-1-4 


\section{The $3^{\text {rd }}$ UAD TEFL International Conference 2014}

Nyaumwe, L. J., \& Mtetwa, D. K. 2006. Efficacy of college lecturer and student peer collaborative assessment of in-service Mathematics students teachers' teaching practice instruction. The Mathematics Educator, 16(2), 35-42.

Philpott, J. 2009. Captivating your class: Effective teaching skills. London: Continuum.

Schulz, M. M. 2009. Effective writing assessment and instruction for young English language learners. Early Childhood Education Journal, 37, 57-62.

Sluijsmans, D. M. A., Brand-Gruwel, S., \& Marriënboer, G. V. 2002. Peer assessment training in teacher education: Effects on performance and perceptions. Assessment \& Evaluation in Higher Education, 27(5), 443-454.

Sivan, A. 2000. The implementation of peer assessment: An action research approach. Assessment in Education, 7(2), 193-286.

Topping, K. J., Smith, E. F., Swanson, I., \& Elliot, A. 2000. Formative peer assessment of academic Writing between postgraduate students. Assessment \& Evaluation in Higher Education, 25(2), 149-166.

Topping, K. 1998. Peer assessment between students in colleges and universities. Review of Educational Research, 68(3), 249-276.

Proceedings of The $3^{\text {rd }}$ UAD TEFL International Conference 2014

"Materials Development in Asia and Beyond: Directions, Issues, and Challenges"

September 17-18, 2014, Yogyakarta, Indonesia

Organized by English Education Department, Universitas Ahmad Dahlan

ISBN: 978-602-18907-1-4 